Key Words:

Chloride Washing Salt Plutonium

Retention: Permanent

Tracking No. 10560

\title{
CHLORIDE REMOVAL FROM SIMULATED 3013 SOLIDS
}

\author{
R. A. Pierce
}

AUGUST 2006

Washington Savannah River Company 


\section{DISCLAIMER}

This report was prepared for the United States Department of Energy under Contract No. DE-AC09-96SR18500 and is an account of work performed under that contract. Neither the United States Department of Energy, nor WSRC, nor any of their employees makes any warranty, expressed or implied, or assumes any legal liability or responsibility for accuracy, completeness, or usefulness, of any information, apparatus, or product or process disclosed herein or represents that its use will not infringe privately owned rights. Reference herein to any specific commercial product, process, or service by trade name, trademark, name, manufacturer or otherwise does not necessarily constitute or imply endorsement, recommendation, or favoring of same by Washington Savannah River Company or by the United States Government or any agency thereof. The views and opinions of the authors expressed herein do not necessarily state or reflect those of the United States Government or any agency thereof.

Printed in the United States of America

Prepared For

U.S. Department of Energy 


\section{REVIEWS AND APPROVALS}

$8 / 22 / 06$

R. A. Pierce, Separations Science Programs

Date

M. L. Crowder, Technical Reviewer, Separations Science Programs $\frac{\text { August } 24,2006}{\text { Date }}$ A. M.Murray, Level3 Manager, Actinide Technology 2006 $8 / 24 / 06$ C. H. Brown, Technical Reviewer, HB-Line Engineering Date

\begin{tabular}{lr} 
J. B. Scblaade, Level 3 Manager, HB-Line Engineering & 9-28-06 \\
\cline { 2 - 2 } & Date
\end{tabular}




\section{Introduction}

HB-Line is evaluating methods for removal of chloride from chloride-bearing plutonium $(\mathrm{Pu})$ residues to permit processing of the $\mathrm{Pu}$ in HB-Line. Most of the Pu considered for these studies is stored as plutonium dioxide $\left(\mathrm{PuO}_{2}\right)$. Some of the $\mathrm{PuO}_{2}$ contains varying amounts of chloride salt, typically less than $25 \mathrm{wt} \%$. Several methods for washing similar materials have been evaluated at Pacific Northwest National Laboratory (PNNL) and shown to be effective. (Gerber and Sevigny, 2002) Comparable demonstrations have also been conducted at Lawrence Livermore National Laboratory (LLNL). (Dodson, et al., 2006) The methods all involve dissolving the chloride salts away from the $\mathrm{PuO}_{2}$ using water. The $\mathrm{Pu}$ processing in HB-Line is part of the program to destructively evaluate 3013 storage containers in the K-Area Material Storage (KAMS) facility.

The Savannah River National Laboratory (SRNL) is participating in the evaluation of an alternate washing technique that contacts the contents of the 3013 containers with water. The solids are expected to contain sodium chloride $(\mathrm{NaCl})$, potassium chloride $(\mathrm{KCl})$, magnesium chloride $\left(\mathrm{MgCl}_{2}\right)$, and calcium chloride $\left(\mathrm{CaCl}_{2}\right)$. The expected chloride salts are known to dissolve in water. It is important to minimize the amount of liquid waste generated because the liquid must be immobilized prior to disposal. The Actinide Technology Section (ATS) is defining the baseline washing performance for evaluating production-scale process options.

\section{Experimental}

Simulant development had several objectives: 1) simulate the $\mathrm{PuO}_{2}, 2$ ) simulate the major chloride-bearing materials, 3) provide worst-case conditions for chloride concentration, and 4) prepare the simulant in a manner that has significant potential for embedding chloride in the $\mathrm{PuO}_{2}$ simulant. Ceric oxide $\left(\mathrm{CeO}_{2}\right)$ is a common simulant for $\mathrm{PuO}_{2}$ and was selected for these tests. The primary chloride salt for the 3013 samples is a 50:50 mixture of $\mathrm{NaCl}$ and $\mathrm{KCl}$; other minor chloride compounds such as $\mathrm{MgCl}_{2}$ and $\mathrm{CaCl}_{2}$ were omitted because they are expected to dissolve in a manner similar to $\mathrm{NaCl}$ and $\mathrm{KCl}$. Expectations are that 3013 samples will contain no more than $25 \mathrm{wt} \%$ chloride salt. Consequently, surrogates were made with $33 \%$ and $50 \% \mathrm{NaCl}-\mathrm{KCl}$. A small amount of ferric oxide $\left(\mathrm{Fe}_{2} \mathrm{O}_{3}\right)$ was added with the thought that it might interact with $\mathrm{NaCl}-\mathrm{KCl}$ and simulate the presence of plutonium trichloride $\left(\mathrm{PuCl}_{3}\right)$.

The 50:50 NaCl- $\mathrm{KCl}$ mixture was prepared by weighing out equal amounts of $\mathrm{NaCl}$ and $\mathrm{KCl}$ in a quartz crucible, heating to $830{ }^{\circ} \mathrm{C}$ for 90 minutes, and then cooling to room temperature. Once cooled, the $\mathrm{NaCl}-\mathrm{KCl}$ was ground into a powder using a mortar and pestle. To prepare a simulant that could entrap chloride in the $\mathrm{CeO}_{2}$ matrix, low-fired $\mathrm{CeO}_{2}$ was produced from cerium oxalate hydrate. Cerium oxalate hydrate was calcined at $450{ }^{\circ} \mathrm{C}$ for two hours to yield low-fired $\mathrm{CeO}_{2}$. Low-fired $\mathrm{CeO}_{2}$ is more porous and has a higher surface than high-fired $\mathrm{CeO}_{2}$. When heated to a higher temperature, the crystal structure of the low-fired $\mathrm{CeO}_{2}$ collapses and has the potential to embed chloride salt. Measurements of $\mathrm{CeO}_{2}$ specific surface area at $450{ }^{\circ} \mathrm{C}, 600{ }^{\circ} \mathrm{C}, 700{ }^{\circ} \mathrm{C}$ and $900{ }^{\circ} \mathrm{C}$ have been reported as 70, 37, 4 and $<1 \mathrm{~m}^{2} / \mathrm{g}$, respectively. (Altas and Tel, 2001) Analogous 
data for $\mathrm{PuO}_{2}$ has measured specific surface areas of $44.8,3.3$, and $0.09 \mathrm{~m}^{2} / \mathrm{g}$ for samples calcined at $500{ }^{\circ} \mathrm{C}, 950{ }^{\circ} \mathrm{C}$, and $1700{ }^{\circ} \mathrm{C}$, respectively. (Bray, et al., 1986) Low-fired $\mathrm{CeO}_{2}, \mathrm{Fe}_{2} \mathrm{O}_{3}$, and $\mathrm{NaCl}-\mathrm{KCl}$ were blended in the appropriate amounts in a quartz crucible and heated to $850{ }^{\circ} \mathrm{C}$ for two hours. After heating, the mixture was cooled and ground into a powder for wash testing.

Two scoping tests were conducted. The first test was conducted with a surrogate made of $65 \mathrm{wt} \% \mathrm{CeO}_{2}, 33 \mathrm{wt} \% \mathrm{KCl} / \mathrm{NaCl}$, and $2 \mathrm{wt} \% \mathrm{Fe}_{2} \mathrm{O}_{3}$. Tests started with three samples one containing powder, another pellets, and a third chunks (see Figure 1) - containing 50 $\mathrm{g}$ of surrogate in $75 \mathrm{~mL}$ of deionized $\mathrm{H}_{2} \mathrm{O}$. All three were washed at ambient temperature in a shaker bath. The pellets and chunks disintegrated into a fine powder shortly after testing began. As a result, data was only collected for the washing of the chunks. Water samples $(1 \mathrm{~mL})$ were withdrawn at 15, 30, 45, 75 and 120 minutes for analysis of chloride content. After two hours, the water was decanted and a fresh batch of $\mathrm{H}_{2} \mathrm{O}$ added. The protocol was repeated for a total of four washes. Samples were submitted for chloride analysis using ion chromatography (IC).

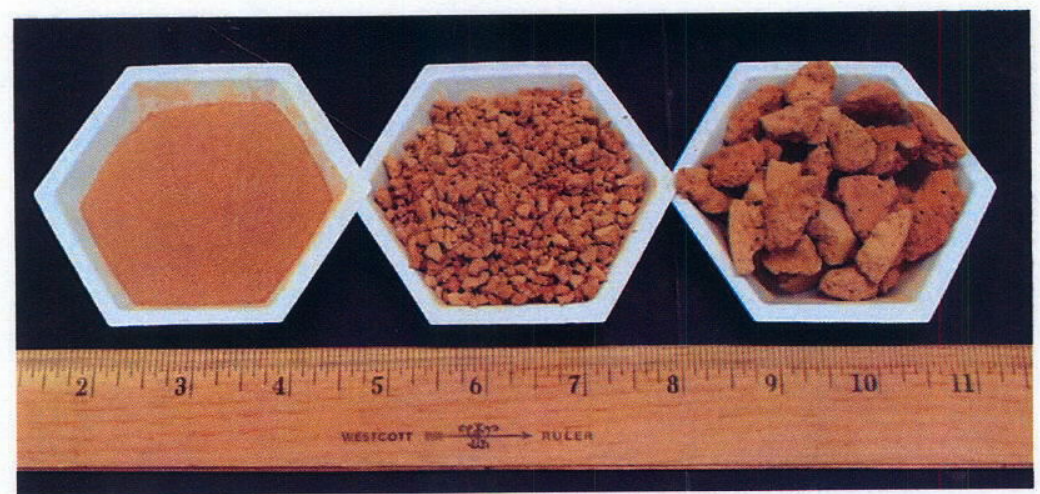

Figure 1. Test \#1 Surrogate Samples

For the second test, one sample was prepared containing a mixture of powder, pellets and chunks. The second test was conducted with a surrogate made of $50 \mathrm{wt} \% \mathrm{CeO}_{2}, 48 \mathrm{wt} \%$ $\mathrm{KCl} / \mathrm{NaCl}$, and $2 \mathrm{wt} \% \mathrm{Fe}_{2} \mathrm{O}_{3}$. Deionized $\mathrm{H}_{2} \mathrm{O}$ was added to $21.2 \mathrm{~g}$ of the surrogate and washed at ambient temperature in a shaker bath. A total of four washes lasting as long as $180 \mathrm{~min}$ each were conducted. The first two washes used $75 \mathrm{~mL}$ of $\mathrm{H}_{2} \mathrm{O}$ and the last two used $50 \mathrm{~mL}$ of $\mathrm{H}_{2} \mathrm{O}$. After the first wash, the solids were allowed to settle briefly and the $\mathrm{H}_{2} \mathrm{O}$ decanted; the solids were filtered through a 0.45 -micron filter after the final three washes. Water samples $(1 \mathrm{~mL})$ were periodically withdrawn for analysis of chloride content using IC. The final filtered solids were rinsed with water and added to $150 \mathrm{~mL}$ of $8 \mathrm{M}$ nitric acid with $0.1 \mathrm{M}$ potassium fluoride at $95{ }^{\circ} \mathrm{C}$ for three hours. The resulting solution was cooled and analyzed for chloride using IC. 


\section{Results and Discussion}

\section{$\underline{\text { Test \#l }}$}

The data for Test \#1 are in Attachment 1. In Test \#1, the first wash reached a maximum almost immediately. The last three washes, as evidenced by the chloride concentration at 15 minutes, show the effect of residual chloride from the previous wash due to decanting of the liquid. The first and second wash data show that the chloride concentration between the washes decreases by a factor of six. The last three washes decrease in chloride concentration by a factor of about three between washes. The last three washes also suggest that all of the chloride has not yet been washed from the solids because the chloride values gradually increase throughout the respective wash cycles. Even the fourth wash cycle shows a steady increase from $1090 \mathrm{mg} / \mathrm{L}$ to $1850 \mathrm{mg} / \mathrm{L}$ over a 120 minute period. The small increase in the fourth wash suggests that the undissolved chloride is small in comparison with the initial concentration. It also indicates that a longer cycle time for the second wash can be used to improve recovery in the second wash. Although there is enough error in the ion chromatography data, particularly with the magnitude and fluctuation of the chloride concentrations for the first wash cycle, the data indicate effective removal of chloride from the solid.

A calculation of a mass balance indicates that nearly all of the chloride (97.8\%) has been recovered in the wash solution, but that there is still a small amount remaining in the solid or unaccounted for because of experimental error. The conclusion that a small amount of undissolved chloride remains in the undissolved solids is consistent with the data showing a gradual increase in chloride concentration with time as salts are washed in the last three wash steps. The mass balance calculation assumes that the chloride concentration for the first wash is $92,400 \mathrm{mg} / \mathrm{L}$ after 120 minutes. However, if one assumes the higher value measured at 75 minutes, the mass balance improves to $99.0 \%$. The recovery percentages may be skewed high because any liquid not decanted will also be counted as part of the next wash. An evaluation of the data after $15 \mathrm{~min}$ for the last three washes indicates that as much as $50 \%$ of the chloride in the last three washes may be attributed to residual chloride not decanted from the first wash. If $50 \%$ of the chloride for the last three washes was attributable to the residual liquid, the total chloride recovered in the wash solutions drops to $87.7 \%$.

\section{$\underline{\text { Test } \# 2}$}

The data for Test \#2 are in Attachment 2. For Test \#2, the wash $\mathrm{H}_{2} \mathrm{O}$ to chloride ratios were adjusted with more water being added to the first two washes (from $0.22 \mathrm{~g}$ of $\mathrm{KCl} / \mathrm{NaCl}$ per $\mathrm{mL}$ of $\mathrm{H}_{2} \mathrm{O}$ for Test \#1 to 0.14 for Test \#2). The wash cycle times were also increased. Another major difference involved liquid removal following the wash steps. After the first wash, the liquid was decanted more carefully than Test \#1 to minimize residual liquid. After each of the last three washes, the solids were filtered.

The results for Test \#2 are similar to those of Test \#1. While the data show that Test \#2 required only two washes to dissolve virtually all chloride compared to four washes for 
Test \#1, this is misleading. Comparing the volume of $\mathrm{H}_{2} \mathrm{O}$ used for two washes in Test \#2 with four washes in Test \#1 reveals $0.030 \mathrm{~g}$ chloride $/ \mathrm{mL} \mathrm{H}_{2} \mathrm{O}$ for Test \#1 and $0.038 \mathrm{~g}$ chloride/ $\mathrm{mL} \mathrm{H}_{2} \mathrm{O}$ for Test \#2. Considering the test variations, the wash efficiency for the two tests is comparable.

A significant difference between the two tests relates to the difference between decanting and filtering. For Test $\# 1$, the difference in measured chloride concentration between washes ranged from a factor of three to six. For Test \#2, the difference was about a factor of ten. The difference is the result of better liquid removal using filtration versus decanting.

A calculation of a mass balance suggests that not all the chloride has been removed (91.2\%). As with Test \#1, the recovery percentages may be skewed high because any liquid not decanted or filtered will also be counted as part of the next wash. This is evident by the fact that the third and fourth washes have chloride in the first sample, but show no increase thereafter. An evaluation of the data for the last three washes suggests that as much as $90 \%$ of the chloride in the last three washes may be attributed to residual chloride not decanted from the first wash. If $90 \%$ of the chloride for the last three washes is attributed to the residual liquid, the overall mass balance drops to $83.9 \%$.

Any concern about undissolved chloride in the solid residue is eliminated by the analysis of chloride in the residual solids. The residual solids were dissolved in $150 \mathrm{~mL}$ of $8 \mathrm{M}$ nitric acid $\left(\mathrm{HNO}_{3}\right)$ with $0.1 \mathrm{M}$ potassium fluoride $(\mathrm{KF})$ at $95{ }^{\circ} \mathrm{C}$ for three hours. Although only about $50 \%$ of the solids dissolved, the solution was a dark orange color, indicative of the dissolution of $\mathrm{CeO}_{2}$. The aggressive dissolution step is expected to dissolve any residual chloride. The chloride concentration of the final dissolution liquid was below the IC detection limit of $20 \mathrm{mg} / \mathrm{L}$. A worst-case calculation, using a solution concentration of $20 \mathrm{mg} / \mathrm{L} \mathrm{Cl}^{-}$, yields a total chloride amount in solution of $0.003 \mathrm{~g}$, which is $0.05 \%$ of the initial chloride. Assuming that none of the $\mathrm{CeO}_{2}$ or $\mathrm{Fe}_{2} \mathrm{O}_{3}$ was dissolved during washes with $\mathrm{H}_{2} \mathrm{O}$, the final chloride concentration in the washed oxide would be $280 \mathrm{ppm}\left(3000 \mu \mathrm{g} \mathrm{Cl}^{-} / 10.6 \mathrm{~g}\right.$ undissolved oxide), or three orders of magnitude reduction in $\mathrm{Cl}^{-}$concentration.

The result for the undissolved solids leads to questions about the mass balance. The discrepancy cannot be attributed to analytical uncertainty alone. One explanation may be tied to the preparation of the surrogate. It is known that the heating of $\mathrm{NaCl} / \mathrm{KCl}$ to melting can cause volatilization of some of the salt. Also, if moisture is present while heating in air, some chloride salts such as magnesium chloride and calcium chloride can react and form oxides. The conversion of some of the salt to an oxide could lead to a low mass balance because the masses of simulant weighed into each sample assume that the $\mathrm{NaCl} / \mathrm{KCl}$ salt exists only as chloride. 


\section{Conclusions}

Testing at SRNL indicates that washing of chloride salts with water can effectively remove the salt from oxide materials used to simulate $\mathrm{Pu}$ oxide. An aggressive dissolution using a flowsheet comparable to the HB-Line $\mathrm{PuO}_{2}$ dissolution flowsheet (8 $\mathrm{M} \mathrm{HNO}_{3} / 0.1 \mathrm{M} \mathrm{KF}$ at $95{ }^{\circ} \mathrm{C}$ for 3 hours) was conducted on the residual solids. The extra dissolution removed only $0.1 \%$ of the initial chloride in the test simulant, thus confirming the potential effectiveness of washing with water. Optimal loading for the first wash is between 0.14 and $0.22 \mathrm{~g}$ of chloride salt per $\mathrm{mL}$ of $\mathrm{H}_{2} \mathrm{O}$. It may be possible to dissolve all of the chloride with the first wash using a chloride loading between 0.14 and $0.22 \mathrm{~g}$ chloride salt $/ \mathrm{mL} \mathrm{H}_{2} \mathrm{O}$. Subsequent rinsing will be necessary to remove chloridecontaining liquid from the interstitial spaces of the undissolved solid. Analysis of the chloride content of $3013 \mathrm{Pu}$ materials can be performed in SRNL prior to processing them in HB-Line. Using filtration to separate the undissolved solids from the wash $\mathrm{H}_{2} \mathrm{O}$ is about a factor of 2 better than decanting.

\section{References}

Y. Altas and H Tel, "Structural and Thermal Investigations on Cerium Oxalate and Derived Oxide Powders for the Preparation of (Th,Ce)O 2 Pellets," J Nuc Mat; 298 (2001) 316-320.

L. A. Bray, J. L. Ryan and E. J. Wheelwright, "Electrochemical Process for Dissolving Plutonium Dioxide and Leaching Plutonium from Scrap or Wastes," PNL-SA-13738, Pacific Northwest National Laboratory, November 1986.

K. E. Dodson, W. L. Close, O. H. Krikorian and H. V. Summers III, "Operation of the Oxide Washer for Water-Washing Solubles," UCRL-TR-220688, Lawrence Livermore National Laboratory, January 2006.

M. Gerber and G. Sevigny, "Technical Evaluation of Candidate Alternatives for Treating High Chloride Content Plutonium Oxides and the Plutonium Finishing Plant," Letter Report for Fluor Hanford, Pacific Northwest National Laboratory, April 2002. 
ATTACHMENT 1 - Test \#1 Data

ION CHROMATOGRAPHY DATA - CHLORIDE CONCENTRATION (mg/L)

\begin{tabular}{|c|c|c|c|c|}
\hline & \multicolumn{4}{|c|}{ Wash Cycle } \\
\hline Wash Time (min) & $\underline{\mathbf{1}}$ & $\underline{\mathbf{2}}$ & $\underline{\mathbf{3}}$ & $\underline{\mathbf{4}}$ \\
\hline $\mathbf{1 5}$ & 91500 & 12000 & 2770 & 1090 \\
\hline $\mathbf{3 0}$ & 93400 & 13900 & 3590 & 1290 \\
\hline $\mathbf{4 5}$ & 90200 & 14600 & 4490 & 1590 \\
\hline $\mathbf{7 5}$ & 93900 & 15200 & 4870 & 1710 \\
\hline $\mathbf{1 2 0}$ & 92400 & 16600 & 5830 & 1850 \\
\hline $\mathbf{g} \mathbf{K C l}-\mathbf{N a C l} \mathbf{m} \mathbf{L} \mathbf{H}_{\mathbf{2}} \boldsymbol{O}^{*}$ & 0.22 & 0.22 & 0.22 & 0.22 \\
\hline
\end{tabular}

* based on initial solid added to the test

CHLORIDE IN LIQUID SAMPLES/ALIQUOTS (g)

\begin{tabular}{|c|c|c|c|c|}
\hline \multirow{2}{*}{$\begin{array}{c}\text { Wash Time } \\
\text { (min) }\end{array}$} & \multicolumn{4}{|c|}{ Wash Cycle } \\
\cline { 2 - 5 } & $\underline{\mathbf{1}}$ & $\underline{\mathbf{2}}$ & $\underline{\mathbf{3}}$ & $\underline{\mathbf{4}}$ \\
\hline $\mathbf{1 5}$ (1-mL sample) & 0.092 & 0.012 & 0.003 & 0.001 \\
\hline $\mathbf{3 0}$ (1-mL sample) & 0.093 & 0.014 & 0.004 & 0.001 \\
\hline $\mathbf{4 5}$ (1-mL sample & 0.090 & 0.015 & 0.004 & 0.002 \\
\hline $\mathbf{7 5}$ (1-mL sample) & 0.094 & 0.015 & 0.005 & 0.002 \\
\hline $\mathbf{1 2 0}$ (71 mL left) & 6.560 & 1.179 & 0.414 & 0.131 \\
\hline Total Ct in wash $(\boldsymbol{g})$ & 6.929 & 1.235 & 0.430 & 0.137 \\
\hline
\end{tabular}

\section{MASS BALANCE DATA}

\begin{tabular}{|l|c|}
\hline Simulant Weight $(\mathrm{g})$ & 50 \\
\hline $\mathrm{Wt} \% \mathrm{NaCl} / \mathrm{KCl}$ & 33 \\
\hline $\mathrm{Wt}(\mathrm{g}) \mathrm{NaCl} / \mathrm{KCl}$ & 16.50 \\
\hline Total $\mathrm{Wt} \mathrm{Cl}(\mathrm{g})$ & 8.93 \\
\hline Mass Balance $\%$ & 97.8 \\
\hline
\end{tabular}


ATTACHMENT 2 - Test \#2 Data

ION CHROMATOGRAPHY DATA - CHLORIDE CONCENTRATION (mg/L)

\begin{tabular}{|c|c|c|c|c|}
\hline & \multicolumn{4}{|c|}{ Wash Cycle } \\
\hline Wash Time (min) & $\underline{\mathbf{1}}$ & $\underline{\mathbf{2}}$ & $\underline{\mathbf{3}}$ & $\underline{\mathbf{4}}$ \\
\hline $\mathbf{1 5}$ & 57000 & 5100 & 563 & ---- \\
\hline $\mathbf{4 5}$ & ---- & 5370 & 551 & 57 \\
\hline $\mathbf{7 5}$ & 60400 & 5460 & 598 & ---- \\
\hline $\mathbf{1 2 0}$ & 61100 & 5560 & 566 & 60 \\
\hline $\mathbf{1 8 0}$ & ---- & 5500 & 582 & 60 \\
\hline $\mathbf{g ~} \mathbf{K C l}-\mathbf{N a C l} \mathbf{m} \mathbf{m} \mathbf{H}_{2} \boldsymbol{O}^{*}$ & 0.14 & 0.14 & 0.21 & 0.21 \\
\hline
\end{tabular}

CHLORIDE IN LIQUID SAMPLES/ALIQUOTS (g)

\begin{tabular}{|c|c|c|c|c|}
\hline $\begin{array}{c}\text { Wash Time } \\
(\mathbf{m i n})\end{array}$ & \multicolumn{4}{|c|}{ Wash Cycle } \\
\cline { 2 - 5 } & $\underline{\mathbf{1}}$ & $\underline{\mathbf{2}}$ & $\underline{\mathbf{3}}$ & $\underline{\mathbf{4}}$ \\
\hline $\mathbf{1 5}$ (1-mL sample) & 0.057 & 0.005 & 0.001 & ---- \\
\hline $\mathbf{3 0}$ (1-mL sample) & ---- & 0.005 & 0.001 & 0.000 \\
\hline $\mathbf{4 5}$ (1-mL sample & 0.060 & 0.005 & 0.001 & ---- \\
\hline $\mathbf{7 5}$ (1-mL sample) & 4.460 & 0.006 & 0.001 & 0.000 \\
\hline $\mathbf{1 2 0}$ (residual wash) & ---- & 0.391 & 0.027 & 0.003 \\
\hline Total Cl in wash $(\mathbf{g})$ & 4.577 & 0.412 & 0.031 & 0.003 \\
\hline
\end{tabular}

MASS BALANCE DATA

\begin{tabular}{|l|c|}
\hline Simulant Weight $(\mathrm{g})$ & 21.2 \\
\hline $\mathrm{Wt} \% \mathrm{NaCl} / \mathrm{KCl}$ & 48 \\
\hline $\mathrm{Wt}(\mathrm{g}) \mathrm{NaCl} / \mathrm{KCl}$ & 10.2 \\
\hline Total $\mathrm{Wt} \mathrm{Cl}(\mathrm{g})$ & 5.51 \\
\hline Mass Balance $\%$ & 91.2 \\
\hline
\end{tabular}

